\title{
PRODUCTION OF Colubrina glandulosa SEEDLINGS WITH DIFFERENT MYCORRHIZAL INOCULA
}

\author{
Ana Caroline Rodrigues Silva ${ }^{1}$, Rodrigo Camara ${ }^{2}$, Marcos Gervasio Pereira ${ }^{3 *}$, Joel Quintino Oliveira Júnior ${ }^{4}$, \\ João Elves da Silva Santana ${ }^{5} \&$ Eduardo Vinícius Silva ${ }^{6}$ \\ ${ }^{1}$ Programa de Pós-Graduação em Ciências Ambientais e Florestais, Universidade Federal Rural do Rio de Janeiro, Seropédica, RJ, Brasil - e- \\ mail: aana.r@hotmail.com , ${ }^{2}$ rcamara73@gmail.com , ${ }^{4}$ joelquintino@yahoo.com.br , 5 joao-elves@outlook.com \\ ${ }^{3 *}$ Departamento de Solos, Instituto de Agronomia, Universidade Federal Rural do Rio de Janeiro, Seropédica, RJ, Brasil - e -mail: \\ mgervasiopereira01@gmail.com , ${ }^{6}$ eduvini@gmail.com
}

Received for publication on: 03/08/2018 - Accepted for publication on: 05/08/2020

\begin{abstract}
Resumo
Produção de mudas de Colubrina glandulosa com diferentes inóculos micorrízicos. Colubrina glandulosa é uma espécie com potencial para o reflorestamento de áreas perturbadas. Mudas inoculadas com fungos micorrízicos arbusculares (FMA) podem ser produzidas com biossólido, proveniente de Estações de Tratamento de Esgoto. Esse trabalho objetivou avaliar a resposta de mudas de Colubrina glandulosa à inoculação isolada ou mista de diferentes espécies de FMA, em substrato à base de biossólido, em casa de vegetação. $\mathrm{O}$ delineamento experimental foi inteiramente casualizado, com 32 repetições (mudas)/tratamento e cinco tratamentos: (1) controle ou ausência de inoculação (CT); (2) inoculação com Dentiscutata heterogama (DH); (3) inoculação com Gigaspora margarita (GM); (4) inoculação com Rhizophagus clarus (RC); (5) inoculação com a mistura das três espécies de FMA (MT). Aos 30, 60, 90, 120 e 140 dias após a instalação do experimento, avaliou-se a altura e diâmetro do coleto. Aos 140 dias, avaliou-se a biomassa seca da parte aérea (SDM), do sistema radicular (RDM) e total; razão SDM / RDM; Índice de Qualidade de Dickson; incremento relativo em altura, diâmetro do coleto e biomassa de parte aérea; conteúdo de nutrientes $(\mathrm{N}, \mathrm{P}, \mathrm{K})$ na parte aérea e sistema radicular; eficiência de absorção e de utilização de nutrientes; taxa de colonização micorrízica da raiz. No geral, os maiores valores das variáveis de crescimento e nutrição analisadas ocorreram no tratamento MT, o qual foi recomendado, na comparação com CT, DH, GM e RC. As taxas de colonização foram baixas $(\leq 20 \%)$, independentemente do inóculo micorrízico, devido aos elevados teores de fósforo no biossólido.

Palavras-chave: Biossólido; biomassa; fungos micorrízicos arbusculares; simbiose micorrízica.
\end{abstract}

\begin{abstract}
Colubrina glandulosa has potential for reforestation of disturbed areas. Seedlings inoculated with arbuscular mycorrhizal fungi (AMF) can be produced with biosolids from Sewage Treatment Plants. This study aimed to evaluate the response of Colubrina glandulosa seedlings to isolated or mixed inoculation of different AMF species on a biosolid-based substrate under greenhouse conditions. The experimental design was completely randomized, with 32 replicates (seedlings)/treatment and five treatments: (1) control or absence of inoculation (CT); (2) inoculation with Dentiscutata heterogama (DH); (3) inoculation with Gigaspora margarita (GM); (4) inoculation with Rhizophagus clarus (RC); (5) inoculation with the mixture of the three AMF species (MT). We evaluated height and collar diameter of the seedlings at 30,60, 90, 120, and 140 days after the experiment installation. We evaluated shoot dry biomass (SDM), root dry biomass (RDM), and total dry biomass; SDM / RDM ratio; Dickson Quality Index; relative increments in height, collar diameter, and shoot biomass; nutrient content $(\mathrm{N}, \mathrm{P}, \mathrm{K})$ in the shoots and roots; efficiency of absorption and utilization of nutrients; rate of root mycorrhizal colonization, at 140 days. In general, the highest values of growth and nutrition variables occurred in the MT treatment, which was recommended, in comparison with CT, DH, GM, and RC. Colonization rates were low $(\leq 20 \%)$, regardless of the mycorrhizal inoculum, due to the high levels of phosphorus in the biosolid. Keywords: Biosolid; biomass; arbuscular mycorrhizal fungi; mycorrhizal symbiosis.
\end{abstract}

\section{INTRODUCTION}

Colubrina glandulosa Perkins (popularly known as "saguaraji-vermelho" or "sobrasil") belongs to the Rhamnaceae family. This initial secondary tree species has rapid growth and can be planted in full sun, which promotes the formation of a microclimate favorable to the growth and establishment of forest species of more advanced successional groups, which require greater shading (SILVA et al., 2015). Additionally, Colubrina glandulosa has a high capacity of spatial occupation, from the regrowth of roots in Atlantic Forest areas that are under conditions of frequent fires (RODRIGUES et al., 2004). In the Amazon Forest biome, this species was among those that had the most satisfactory growth, in a plantation for reforestation of a degraded pasture area (GAMA et al., 2013). Thus, Colubrina glandulosa can be considered a key species in reforestation plantations of disturbed areas. Therefore, studies should be carried out focusing on the production of seedlings with higher quality, for the use in forest recovery programs. This context includes investigations about the inoculation of seedlings with arbuscular mycorrhizal fungi (AMF), which show higher quality when compared to non-inoculated seedlings (SCABORA et al., 2010; OLIVEIRA JÚNIOR et al., 2017).

FLORESTA, Curitiba, PR, v. 50, n. 4, p. 1731 - 1740, out/dez 2020.

Silva, A. C. R. et.al.

ISSN eletrônico 1982-4688 
Symbiosis between plants and AMF promotes benefits in growth and nutrition for the former, in addition to savings of more than $60 \%$ in the application of phosphorus in the production of forest seedlings, compared to those not inoculated with AMF (ROCHA et al., 2006). AMF are also able to promote an increase in tolerance and/or resistance of terrestrial plants to water stress, salt stress and presence of heavy metals in soil solution, which are sequestered by glomalin, a protein secreted by these microorganisms that contributes fundamentally to the stability of soil structure (FOLLI-PEREIRA et al., 2012). However, the benefits promoted for plants by the mycorrhizal association depend on several factors, which include the availability of phosphorus in soil solution (OLIVEIRA JÚNIOR et al., 2017), the species of AMF involved (MARTIN et al., 2012) and species of plant host (SCABORA et al., 2010).

Camara et al. (2017) evaluated the effect of single inoculation of Rhizophagus clarus Becker and Gerdemann (previously classified as Glomus clarum Nicolson and Schenck), Gigaspora margarita Becker and Hall, Dentiscutata heterogama (Nicol and Gerd) Walker and Sanders and mixed inoculation with the three AMF species on the production of Colubrina glandulosa seedlings in different substrate formulations, in a greenhouse. These authors concluded that the seedlings inoculated with mixed inoculum and produced on substrate consisting of $60 \%$ of soil from A horizon, $20 \%$ of bovine manure, $10 \%$ of sand and $10 \%$ of vermiculite had the best nutritional and growth conditions. The superiority of mixed inoculation of AMF was observed in other studies (OLIVEIRA JÚNIOR et al., 2017). However, this pattern does not occur in some situations, in which seedlings of tree species with higher quality can be obtained through inoculation with only one species of AMF, in comparison with the mixed inoculum (MACHINESKI et al., 2009). Also, in other situations, there may be no differences between the effect of mixed inoculum and the effect of single inoculation with a certain species of AMF on the seedlings produced (CARMO et al., 2016).

This panorama shows the relevance of investigating the effect of different AMF inocula, using the same substrate formulation, for the production of seedlings of Colubrina glandulosa, among other tree species that can be used in the reforestation of disturbed areas. In this context, it is possible to use sewage sludge from Sewage Treatment Plants (STP), which constitutes an organic material that is rich in nutrients called biosolid, after the stabilization process (GOMES et al., 2013; ABREU et al., 2019). Thus, the biosolid enables the production of quality seedlings for the reforestation of disturbed areas (TRIGUEIRO; GUERRINI, 2014), whose destination becomes more environmentally sustainable when compared to its disposal in landfills (GOMES et al., 2013).

The present study aims to evaluate the growth and nutritional status Colubrina glandulosa seedlings under inoculation with a mixture of different species of AMF (mixed inoculum) and inoculation with a single species of $\mathrm{AMF}$, in a biosolid-based substrate, in a greenhouse. We tested the hypothesis that there is a difference in the response of Colubrina glandulosa seedlings to inoculation with the mixture of three species of AMF (Rhizophagus clarus, Gigaspora margarita and Dentiscutata heterogama), in comparison to inoculation with a single species of $\mathrm{AMF}$ and with the absence of mycorrhizal inoculation.

\section{MATERIAL AND METHODS}

Colubrina glandulosa seedlings were produced in a greenhouse of the Forest Institute of the Federal Rural University of Rio de Janeiro, Seropédica, RJ, Brazil. Containers with volumetric capacity of $980 \mathrm{~mL}$ were used. Each container was filled with approximately $1.0 \mathrm{~kg}$ of substrate consisting of a mixture of $20 \%$ vermiculite and $80 \%$ sewage sludge biosolid, which came from the Alegria Sewage Treatment Plant (STP), located in Rio de Janeiro, RJ. The chemical analysis of the biosolid, on a dry basis $(\%)$, indicated the following results: $\mathrm{pH}\left(\mathrm{H}_{2} \mathrm{O}\right)=$ $5.45 ; \mathrm{N}=33.497 \mathrm{mg} \mathrm{kg}^{-1}$; Total $\mathrm{P}=0.62 \%$ or $6.20 \mathrm{~g} \mathrm{~kg}^{-1}$; Total $\mathrm{K}=0.50 \%$ or $5.0 \mathrm{~g} \mathrm{~kg}^{-1}$; Total Ca $=0.24 \%$ or $2.40 \mathrm{~g} \mathrm{~kg}^{-1}$; Total $\mathrm{Mg}=0.01 \%$ or $0.1 \mathrm{~g} \mathrm{~kg}^{-1}$; Total $\mathrm{Na}=0.16 \%$ or $1.6 \mathrm{~g} \mathrm{~kg}^{-1}$; organic carbon $=28.7 \%$ or 287.00 $\mathrm{g} \mathrm{kg}^{-1}$ (ABREU et al., 2019). This material was moistened and autoclaved (temperature of $120^{\circ} \mathrm{C}$, pressure of 1 atm, 1 hour) three times, with interval of 4 days between each autoclaving procedure (CAMARA et al., 2017).

Seeds of Colubrina glandulosa, which were donated by the Fernando Luiz Oliveira Capellão Forest Nursery, were disinfested with sodium hypochlorite $(\mathrm{NaClO})$ at $2 \%$ for five minutes. Then, dormancy was broken by immersion in concentrated sulfuric acid corresponding to twice its volume, in a glass beaker (BRANCALION et al., 2011). After 15 minutes, the beaker contents were stirred with a glass rod and, after 30 minutes, the seeds were separated and washed in a sieve under running water for 10 minutes. Then, they were placed outdoors on paper towels to drain surface water, on a laboratory bench. Subsequently, the seeds were subjected to a pregermination process in trays containing sand and inside a germination chamber (Biological Oxygen Demand), under constant light and temperature of $28{ }^{\circ} \mathrm{C}$. After two days, the radicle had an average length of $4 \mathrm{~mm}$. Five days after sowing, four pre-germinated seeds were inserted into a small orifice in the substrate of approximately $1.0 \mathrm{~cm}$, in each container, and covered with a thin layer of the substrate itself. Approximately 15 days after this stage, thinning was performed, leaving only the most vigorous seedling in each container (SOUZA et al., 2009).

The experiment was conducted from October 2016 to January 2017, in a completely randomized design. The influence of five treatments on seedling growth and nutritional conditions was investigated, with 32 replicates (seedlings) per treatment, totaling 160 seedlings. The treatments were: (1) control or absence of inoculation with

FLORESTA, Curitiba, PR, v. 50, n. 4, p. 1731 - 1740, out/dez 2020.

Silva, A. C. R. et.al.

ISSN eletrônico 1982-4688 
AMF spores (CT); (2) inoculation with AMF spores of Dentiscutata heterogama (DH) - DHET A2- CNPAB002; (3) inoculation with AMF spores of Gigaspora margarita (GM) - GMAR A1- CNPAB001; (4) inoculation with AMF spores of Rhizophagus clarus (RC) - RCLA A5 - CNPAB005; (5) inoculation with a mixture of spores of the three AMF species (MT). In mycorrhization treatments, 1.0 gram of mycorrhizal inoculum (soil containing approximately 50 AMF spores) was applied at the time of transplanting of the pre-germinated seeds into the containers (CAMARA et al., 2017). The inocula were obtained from the Collection of Arbuscular Mycorrhizal Fungi of Embrapa Agrobiology (COFMEA). Irrigation was carried out daily throughout the experiment.

At 140 days after transplanting the pre-germinated seeds, the seedlings began to show signs that the container was no longer suitable for their full development and, for this reason, the experiment was ended on that date. Shoot height $(\mathrm{H})$ and collar diameter (CD) were evaluated at 30, 60, 90, 120 and 140 days after transplantation, with a graduated ruler and a digital caliper, respectively. CD was not evaluated at 90 days after transplantation due to technical problems in the device on that date. At 140 days after transplanting the pregerminated seeds, the seedlings were removed from the greenhouse and divided into shoots and root system. Subsamples with approximately $0.5 \mathrm{~g}$ of fine roots were separated from 10 randomly selected replicates and subjected to bleaching and staining (KOSKE; GEMMA, 1989; GRACE; STRIBLEY, 1991). Then, the percentage rate of root colonization by AMF (ROOTCOL) was evaluated by the grid-line intersect method (GIOVANNETTI; MOSSE, 1980).

Shoots and root system were dried in a forced air circulation oven $\left(65^{\circ} \mathrm{C}, 72 \mathrm{~h}\right)$ to obtain the values of shoot dry biomass (SDM) and root dry biomass (RDM) on a digital scale with two decimal places. These data were used to calculate total dry biomass (TDM), SDM/ RDM ratio, Dickson Quality Index (DQI) and relative increments in the biomass of shoots (RIB_S), roots (RIB_R) and total (RIB_T). DQI ranges from 0 to 1.0 and was estimated from the following equation: $\mathrm{DQI}=(\mathrm{TDM} /(\mathrm{H} / \mathrm{CD})+(\mathrm{SDM} / \mathrm{RDM}))$. RIB was estimated considering the percentage increments in shoot dry biomass, root dry biomass and total dry biomass, which were promoted by each inoculation treatment (DH, GM, RC or MT), compared to the control (CT) with the following

equation $R I B=\frac{S D M, R D M \text { or } T D M \text { with inoculation-SDM,RDM or TDM in the control }}{S D M, R D M \text { or } T D M \text { in the control }} X 100$

The same equation was used to evaluate the relative increments in shoot height (RIH) and collar diameter (RICD), which considered the $\mathrm{H}$ and $\mathrm{CD}$ values obtained at the last evaluation time (at 140 days after transplanting).

After weighing, the materials were ground and subjected to sulfuric digestion to determine $\mathrm{N}$ content, by the modified Kjeldahl method, P content, by colorimetry, and K content, by flame photometry (TEDESCO et al., 1995). The product of dry mass and nutrient content data were used to calculate the contents of $\mathrm{N}, \mathrm{P}$ and $\mathrm{K}$ in the shoots (N_S, P_S and K_S, respectively) and in the root system (N_R, P_R and K_R, respectively). Then, the absorption efficiency (ABE) and utilization efficiency (NUE) for each nutrient were calculated. ABE makes it possible to evaluate the influence of the treatments on the ability of the plant to extract $\mathrm{N}$ from the substrate, which was converted into dry biomass, and was estimated by the equation proposed by Swiader et al. (1994): $A B E=$ $\left(N_{-} S+N_{-} R\right) /(R D M)$ NUE, which makes it possible to assess how much biomass was produced as a function of $\mathrm{N}$ absorption, was estimated by the equation of Siddiqi and Glass $(1981): N U E=\frac{(T D M) 2}{\left(N_{-} S+N_{-} R\right)}$. The same procedure was performed for $\mathrm{P}$ and $\mathrm{K}$.

To evaluate the influence of the observation period (collection time) on $\mathrm{H}$ and $\mathrm{CD}$, repeated-measures ANOVA was applied. All data obtained were subjected to analysis of variance (One-way ANOVA) and, when the assumption of homogeneity of variances was met by the Levene test, treatment means were compared by the parametric LSD test. Otherwise, the means were compared by the non-parametric Kruskal-Wallis test. All statistical analyses, carried out with version 8.0 of the STATISTICA program, considered $\mathrm{p}<0.05$.

Multivariate analyses were used to assist in the interpretation of the data obtained through version $2.17 \mathrm{c}$ of the PAleontological STatistics (PAST) program. From the dendrogram generated in the hierarchical cluster analysis by Bray-Curtis distance and based on the single linkage method, the objective was to identify possible similarities between treatments. Principal component analysis was performed in order to identify the variables that correlated with the treatments. Both of these analyses considered the mean data of all variables studied, except for RIH, RICD and RIB; in the case of the variables H and CD, the respective means calculated considering all evaluation times were used.

\section{RESULTS}

There was significant interaction between the collection times and the treatments for $\mathrm{H}$ and CD (Table 1). In the comparison between two consecutive times of $\mathrm{H}$ evaluation, significant differences were observed in the effect of treatments between the first and second times and between the fourth and fifth times. There were no significant differences in the increment of $\mathrm{H}$, in the pairs formed by the second and third times and by the third and fourth times.

FLORESTA, Curitiba, PR, v. 50, n. 4, p. 1731 - 1740, out/dez 2020

Silva, A. C. R. et.al.

ISSN eletrônico 1982-4688 
Tabela 1. Análise de variância (One-way ANOVA) para a altura (H) e diâmetro de colo (CD) de mudas de Colubrina glandulosa em diferentes tratamentos de inoculação com fungos micorrízicos aos 30, 60, 90, 120 e 140 dias após o transplantio das sementes pré-germinadas (tempo), em condições de casa de vegetação*.

Table 1. Analysis of variance (One-way ANOVA) of height $(\mathrm{H})$ and collar diameter (CD) of Colubrina glandulosa seedlings at 30,60,90,120, and 140 days after transplanting of pre-germinated seeds (time) in different treatments under greenhouse conditions.

\begin{tabular}{lccccc}
\hline \multicolumn{1}{c}{ Effect } & SS & DF & MS & F & p \\
\hline & \multicolumn{5}{c}{$\mathbf{H}$} \\
\hline Intercept & 67867.84 & 1 & 67867.84 & 7458.81 & 0.000000 \\
Treatment & 220.37 & 4 & 55.09 & 6.06 & 0.000149 \\
Error & 1410.35 & 155 & 9.10 & & \\
Time & 28841.04 & 4 & 7210.26 & 1530.12 & 0.000000 \\
Time ${ }^{*}$ Treatment & 610.80 & 16 & 38.18 & 8.101 & 0.000000 \\
Error & 2921.58 & 620 & 4.71 & & \\
\hline \multicolumn{5}{c}{$\mathbf{C D}$} \\
\hline Intercept & 3777.48 & 1 & 3777.48 & 12284.16 & 0.000000 \\
Treatment & 8.14 & 4 & 2.03 & 6.61 & 0.000061 \\
Error & 47.66 & 155 & 0.31 & & \\
Time & 1549.15 & 3 & 516.38 & 3471.00 & 0.000000 \\
Time * Treatment & 8.29 & 12 & 0.69 & 4.65 & 0.000000 \\
Error & 69.18 & 465 & 0.149 & & \\
\hline
\end{tabular}

"SS: sum of squares; DF: degrees of freedom; MS: mean square; F: calculated F value; p: significance level.

In the comparison between two consecutive times of $\mathrm{CD}$ evaluation, significant differences were observed in the effect of treatments between the first and second times and between the second and third times (Table 1). There were no significant differences in the increment of CD between the third and fourth times.

Based on the mean results, which were calculated from the data found at each of the different evaluation times for these variables, it was possible to identify significant differences between treatments in relation to their effect on $\mathrm{H}$ and CD. By comparing the first and last evaluation times, it was found that the MT treatment caused a greater increase in $\mathrm{H}(1868 \%)$ in absolute terms, compared to the treatments CT, DH, GM and RC (1831\%, $1582 \%, 1623 \%$ and 1423 $\%$, respectively).

In general, this pattern resulted from the superiority of the MT treatment, which significantly influenced higher $\mathrm{H}$ values in comparison with the treatments CT (at 30, 90 and 120 days after experiment installation), GM (at 30 and 120 days), DH (at 30, 120 and 140 days) and RC (at 120 and 140 days) (Table 2). The mean value of $\mathrm{H}$, which was calculated considering the five evaluation dates, was significantly higher in MT, compared to the other treatments, which did not show significant differences from one another.

Tabela 2. Valores médios de altura (H) e diâmetro de colo (CD) de mudas de Colubrina glandulosa em diferentes tratamentos de inoculação com fungos micorrízicos (Trat) aos 30, 60, 90, 120 e 140 dias após o transplantio das sementes pré-germinadas, em condições de casa de vegetação.

Table 2. Mean values of height (H) and collar diameter (CD) of Colubrina glandulosa seedlings at 30, 60, 90, 120 and 140 days after transplanting of pre-germinated seeds, in different treatments of arbuscular mycorrhizal inoculation (Treat) under greenhouse conditions.

\begin{tabular}{|c|c|c|c|c|c|c|c|c|c|c|c|}
\hline \multirow[t]{3}{*}{ Treat } & \multicolumn{6}{|c|}{$\mathbf{H}^{*}$} & \multicolumn{5}{|c|}{ CD* } \\
\hline & \multicolumn{6}{|c|}{ 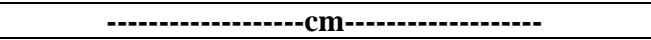 } & \multicolumn{5}{|c|}{ 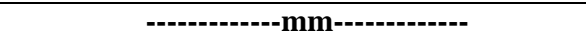 } \\
\hline & 30 & 60 & 90 & 120 & 140 & Mean & 30 & 60 & 120 & 140 & Mean \\
\hline \multirow[t]{3}{*}{ CT } & 2.31 & 3.21 & 6.33 & 11.60 & 20.62 & 8.80 & 0.73 & 0.74 & 3.29 & 4.22 & 2.24 \\
\hline & $\mathrm{C}$ & $\mathrm{C}$ & B & B & $\mathrm{AB}$ & B & B & $\mathrm{C}$ & $\mathrm{C}$ & B & $\mathrm{C}$ \\
\hline & $(0.49)$ & $(0.61)$ & $(1.48)$ & $(2.42)$ & $(4.88)$ & (7.20) & $(0.13)$ & $(0.20)$ & $(0.51)$ & $(0.54)$ & $(1.60)$ \\
\hline \multirow[t]{3}{*}{ DH } & 2.50 & 4.44 & 7.78 & 11.69 & 18.32 & 8.90 & 0.66 & 1.15 & 3.38 & 4.29 & 2.37 \\
\hline & $\mathrm{BC}$ & B & A & B & $\mathrm{BC}$ & B & $\mathrm{CD}$ & B & $\mathrm{BC}$ & $\mathrm{AB}$ & $\mathrm{BC}$ \\
\hline & $(0.42)$ & $(0.77)$ & $(1.20)$ & $(2.45)$ & $(5.41)$ & (6.30) & $(0.14)$ & $(0.29)$ & $(0.49)$ & $(0.65)$ & (1.58) \\
\hline \multirow[t]{3}{*}{ GM } & 2.25 & 3.80 & 7.63 & 11.90 & 18.48 & 8.80 & 0.82 & 1.22 & 3.40 & 4.37 & 2.45 \\
\hline & $\mathrm{C}$ & BC & A & B & $\mathrm{ABC}$ & B & A & $\mathrm{AB}$ & $\mathrm{BC}$ & $\mathrm{AB}$ & B \\
\hline & $(0.66)$ & $(0.72)$ & (1.08) & (2.12) & (3.33) & $(6.20)$ & $(0.10)$ & $(0.24)$ & $(0.48)$ & $(0.49)$ & (1.53) \\
\hline \multirow[t]{3}{*}{$\mathrm{RC}$} & 2.63 & 5.63 & 9.00 & 12.29 & 16.86 & 9.30 & 0.72 & 1.34 & 3.77 & 4.42 & 2.56 \\
\hline & $\mathrm{AB}$ & A & A & B & $\mathrm{C}$ & B & BC & A & A & $\mathrm{AB}$ & A \\
\hline & $(0.50)$ & $(1.29)$ & (2.15) & (2.18) & (2.76) & (5.40) & $(0.10)$ & $(0.26)$ & (0.59) & $(0.56)$ & (1.63) \\
\hline \multirow[t]{3}{*}{ MT } & 2.83 & 4.13 & 8.40 & 14.15 & 21.51 & 10.20 & 0.64 & 1.11 & 3.62 & 4.70 & 2.52 \\
\hline & A & B & A & A & A & A & D & B & $\mathrm{AB}$ & A & A \\
\hline & $(0.52)$ & $(0.80)$ & (2.41) & (2.41) & $(4.46)$ & $(1.40)$ & (0.13) & (U.2J) & $(0.66)$ & (0.78) & (1.78) \\
\hline
\end{tabular}

*Values obtained from the average of 32 replicates/treatment. Values followed by different letters in the column indicate a si gnificant difference between treatments, by the parametric LSD test or non-parametric Kruskal-Wallis test ( $<$ 0.05). CT: control / absence of inoculation of seedlings with spores of arbuscular mycorrhizal fungi (AMF); DH: inoculation of seedlings with Dentiscutata heterogama spores; GM:

FLORESTA, Curitiba, PR, v. 50, n. 4, p. 1731 - 1740, out/dez 2020.

Silva, A. C. R. et.al.

ISSN eletrônico 1982-4688 
inoculation of seedlings with Gigaspora margarita spores; RC: inoculation of seedlings with Rhizophagus clarus spores; MT: inoculation of seedlings with a mixture of spores of the three species of AMF.

The MT treatment also influenced higher absolute values of CD (406\%) compared to the treatments CT, DH, GM and RC (349\%, 363\%, 355 \% and 370\%, respectively). The mean values calculated considering the four evaluation dates revealed that the treatments MT and RC did not differ from each other, and promoted significantly higher values of $\mathrm{CD}$, compared with the other treatments (Table 2).

Considering each of the $\mathrm{CD}$ evaluation dates, there was a wide variation in the effect of treatments on this growth variable. The GM treatment was superior to the others, at 30 days after experiment installation (Table 2). On the other hand, the RC treatment promoted a significant increase in CD compared to the treatments MT (at 60 days), CT and DH (at 60, 120 and 140 days, for both treatments).

Significant differences were also observed between treatments in relation to their effect on RIH, SDM, RDM, TDM, SDM/ RDM, DQI, ROOTCOL, N_S, P_S, ABE_N, NUE_P (Table 3).

Tabela 3. Tabela 1. Análise de variância (One-way ANOVA) para incremento relativo em altura da parte aérea (RIH), biomassa seca da parte aérea, raízes e total (SDM, RDM e TDM, respectivamente), razão SDM / RDM, Índice de Qualidade de Dickson (DQI), taxa percentual de colonização radicular (ROOTCOL), conteúdos na parte aérea de N (N_S) e P (P_S), eficiência de absorção de N (ABE_N) e eficiência de utilização de P (NUE_P) de mudas de Colubrina glandulosa em diferentes tratamentos de inoculação com fungos micorrízicos arbusculares aos 140 dias após o transplantio das sementes pré-germinadas (tempo), em condições de casa de vegetação.

Table 3. Analysis of variance (One-way ANOVA) for relative increment in shoot height (RIH), shoot dry biomass, root dry biomass, and total dry biomass (SDM, RDM and TDM, respectively), SDM / RDM ratio, Dickson Quality Index (DQI), percentage rate of root colonization (ROOTCOL), shoot contents of N (N_S) and P (P_S), absorption efficiency of $\mathrm{N}\left(\mathrm{ABE} \_\mathrm{N}\right)$, and utilization efficiency of P (NUE_P) of Colubrina glandulosa seedlings in different arbuscular mycorrhizal fungi inoculation treatments at 140 days after transplanting of pre-germinated seeds (time), under greenhouse conditions*.

\begin{tabular}{|c|c|c|c|c|c|c|c|c|c|c|}
\hline Effect & SS & DF & MS & $\mathbf{F}$ & p & SS & DF & MS & $\mathbf{F}$ & $\mathbf{p}$ \\
\hline & \multicolumn{5}{|c|}{ RIH } & \multicolumn{5}{|c|}{ SDM } \\
\hline Intercept & 2074.6 & 1 & 2074.59 & 2.19 & 0.140959 & 914.80 & 1 & 914.80 & 1112.46 & 0.000000 \\
\hline Treatment & 9609.9 & 3 & 3203.29 & 3.39 & 0.020224 & 22.61 & 4 & 5.65 & 6.87 & 0.000041 \\
\hline Error & 117176.0 & 124 & 944.97 & & & 127.46 & 155 & 0.82 & & \\
\hline & \multicolumn{5}{|c|}{ RDM } & \multicolumn{5}{|c|}{ TDM } \\
\hline Intercept & 225.36 & 1 & 225.36 & 1637.99 & 0.000000 & 2048.25 & 1 & 2048.25 & 1483.44 & 0.000000 \\
\hline Treatment & 2.88 & 4 & 0.72 & 5.23 & 0.000564 & 24.94 & 4 & 6.24 & 4.52 & 0.001772 \\
\hline Error & 21.33 & 155 & 0.14 & & & 214.02 & 155 & 1.38 & & \\
\hline & \multicolumn{5}{|c|}{ SDM / RDM } & \multicolumn{5}{|c|}{ DQI } \\
\hline Intercept & 700.82 & 1 & 700.82 & 1427.88 & 0.000000 & 51.24 & 1 & 51.24 & 1601.02 & 0.000000 \\
\hline Treatment & 17.90 & 4 & 4.48 & 9.12 & 0.000001 & 0.61 & 4 & 0.15 & 4.78 & 0.001155 \\
\hline Error & 76.08 & 155 & 0.49 & & & 4.96 & 155 & 0.03 & & \\
\hline & \multicolumn{5}{|c|}{ ROOTCOL } & \multicolumn{5}{|c|}{ N_S } \\
\hline Intercept & 4493.52 & 1 & 4493.52 & 31.55 & 0.000001 & 3135.31 & 1 & 3135.31 & 306.29 & 0.000000 \\
\hline Treatment & 1960.28 & 4 & 490.07 & 3.44 & 0.015464 & 285.00 & 4 & 71.25 & 6.96 & 0.000189 \\
\hline Error & 6408.20 & 45 & 142.40 & & & 460.63 & 45 & 10.24 & & \\
\hline & \multicolumn{5}{|c|}{ P_S } & \multicolumn{5}{|c|}{ ABE_N } \\
\hline Intercept & 8.34 & 1 & 8.34 & 124.97 & 0.000000 & 5166.70 & 1 & 5166.70 & 585.75 & 0.000000 \\
\hline Treatment & 0.73 & 4 & 0.18 & 2.75 & 0.039428 & 264.25 & 4 & 66.06 & 7.49 & 0.000103 \\
\hline Error & 3.00 & 45 & 0.07 & & & 396.93 & 45 & 8.82 & & \\
\hline \multicolumn{11}{|c|}{ NUE_P } \\
\hline Intercept & 21447.02 & 1 & 21447.02 & 324.88 & 0.000000 & & & & & \\
\hline Treatment & 1113.66 & 4 & 278.41 & 4.22 & 0.005526 & & & & & \\
\hline Error & 2970.67 & 45 & 66.01 & & & & & & & \\
\hline
\end{tabular}

*SS: sum of squares; DF: degrees of freedom; MS: mean square; F: calculated F value; p: significance level.

The MT treatment promoted significantly higher values of SDM and TDM of the seedlings, compared to the other treatments of AMF inoculation (Table 4). The treatments MT and RC, which did not differ from each other, influenced significantly higher values of DQI and ROOTCOL, compared to CT. Regarding the variables RIH and SDM/RDM ratio, there were no significant differences between MT, CT, DH and GM, whose values were significantly higher than those observed in the RC treatment. On the other hand, the RC treatment influenced significantly higher values of RDM, compared to $\mathrm{CT}$, DH and GM.

Tabela 4. Valores médios de incremento relativo de altura (RIH) e diâmetro de colo (RICD), biomassa de matéria seca da parte aérea (SDM), do sistema radicular (RDM) e biomassa total (TDM), relação massa de matéria seca da parte aérea e do sistema radicular (SDM / RDM), índice de qualidade de Dickson (DQI) e taxa percentual de colonização radicular pelos fungos micorrízicos arbusculares (ROOTCOL) de mudas de Colubrina

FLORESTA, Curitiba, PR, v. 50, n. 4, p. 1731 - 1740, out/dez 2020.

Silva, A. C. R. et.al.

ISSN eletrônico 1982-4688 
glandulosa, em diferentes tratamentos de inoculação com fungos micorrízicos arbusculares (Trat) aos 140 dias após o transplantio das sementes pré-germinadas, em condições de casa de vegetação.

Table 4. Mean values of relative increments of height (RIH) and collar diameter (RICD), shoot (SDM), root (RDM) and total (TDM) dry mass, shoot dry mass/root dry mass ratio (SDM / RDM), Dickson quality index (DQI), and mycorrhizal colonization rate (\% ROOTCOL) of Colubrina glandulosa seedlings at 140 days after transplanting of pre-germinated seeds, in different treatments of arbuscular mycorrhizal fungi inoculation (Treat) under greenhouse conditions.

\begin{tabular}{|c|c|c|c|c|c|c|c|c|}
\hline \multirow[t]{2}{*}{ Treat } & RIH & RICD & SDM* & RDM* & TDM* $*$ & SDM/RDM* & DQI* & ROOTCOL $^{* * *}$ \\
\hline & \multicolumn{2}{|c|}{------\% \%------- } & ------ & ----g----. & ------ & & & $\%$ \\
\hline \multirow[t]{3}{*}{ CT } & - & - & 2.43 & 1.03 & 3.46 & 2.41 & 0.48 & 0 \\
\hline & & & $\mathrm{AB}$ & B & $\mathrm{AB}$ & A & B & B \\
\hline & & & $(0.97)$ & $(0.34)$ & $(1.22)$ & $(0.81)$ & $(0.15)$ & (0) \\
\hline \multirow[t]{3}{*}{$\mathrm{DH}$} & -5.54 & 3.59 & 2.21 & 1.12 & 3.33 & 2.00 & 0.55 & 8 \\
\hline & $\mathrm{AB}$ & A & B & B & B & A & $\mathrm{AB}$ & $\mathrm{AB}$ \\
\hline & $(38.34)$ & $(22.50)$ & $(0.93)$ & $(0.35)$ & $(1.18)$ & $(0.66)$ & $(0.19)$ & (10) \\
\hline \multirow[t]{3}{*}{ GM } & -6.55 & 5.19 & 2.25 & 1.11 & 3.36 & 2.13 & 0.54 & 11 \\
\hline & $\mathrm{AB}$ & A & B & B & B & A & $\mathrm{AB}$ & $\mathrm{AB}$ \\
\hline & (23.71) & $(17.53)$ & $(0.79)$ & $(0.34)$ & $(1.01)$ & $(0.75)$ & $(0.17)$ & (16) \\
\hline \multirow[t]{3}{*}{$\mathrm{RC}$} & -13.91 & 6.41 & 1.98 & 1.40 & 3.38 & 1.51 & 0.65 & 20 \\
\hline & B & A & B & A & B & B & A & A \\
\hline & (24.57) & (19.34) & $(0.56)$ & $(0.41)$ & $(0.84)$ & $(0.65)$ & $(0.18)$ & (17) \\
\hline \multirow[t]{3}{*}{ MT } & 9.90 & 13.53 & 3.09 & 1.28 & 4.36 & 2.42 & 0.62 & 9 \\
\hline & A & A & A & $\mathrm{AB}$ & A & A & A & A \\
\hline & $(33.82)$ & $(25.41)$ & $(1.17)$ & $(0.41)$ & $(1.51)$ & $(0.63)$ & $(0.20)$ & (8) \\
\hline
\end{tabular}

*Values obtained from the average of 32 replicates/treatment. ${ }^{* *}$ Values obtained from the average of 10 replicates/treatment. Values followed by different letters in the column indicate a significant difference between treatments, by the parametric LSD test or non-parametric KruskalWallis test ( $\mathrm{p}<0.05)$. CT: control / absence of inoculation of seedlings with spores of arbuscular mycorrhizal fungi (AMF); DH: inoculation of seedlings with Dentiscutata heterogama spores; GM: inoculation of seedlings with Gigaspora margarita spores; RC: inoculation of seedlings with Rhizophagus clarus spores; MT: inoculation of seedlings with a mixture of spores of the three species of AMF.

The MT treatment led to significantly higher values of N_S, in comparison with GM and RC, and of P_S, in comparation with CT, DH and GM (Table 5). Significantly higher values of ABE_N were verified for seedlings in the MT treatment, compared to CT and RC treatments; of NUE_N in the comparison with DH; and of NUE_P, when compared with GM and RC (Table 6).

Tabela 5. Valores médios de incremento relativo de biomassa da parte aérea (RIB_S), do sistema radicular (RIB_R) e total (RIB_T), conteúdo de nitrogênio, fósforo e potássio na parte aérea (N_S, P_S e K_S, respectivamente), e conteúdo de nitrogênio, fósforo e potássio no sistema radicular (N_R, P_R e K_R, respectivamente) de mudas de Colubrina glandulosa em diferentes tratamentos de inoculação com fungos micorrízicos arbusculares (Trat) aos 140 dias após o transplantio das sementes pré-germinadas, em condições de casa de vegetação.

Table 5. Mean values of relative increment in the biomass of shoots (RIB_S), roots (RIB_R) and total (RIB_T), nitrogen, phosphorus, and potassium contents in shoot (N_S, P_S, and K_S, respectively), nitrogen, phosphorus, and potassium contents in root (N_R, P_R, and K_R, respectively) of Colubrina glandulosa seedlings at 140 after transplanting of pre-germinated seeds, in different treatments of arbuscular mycorrhizal fungi inoculation (Treat) under greenhouse conditions.

\begin{tabular}{|c|c|c|c|c|c|c|c|c|c|}
\hline \multirow{2}{*}{ Treat } & RIB_S* & RIB_R* & RIB_T* & N_S** & P_S $* * *$ & K_S S** $^{\prime}$ & $\mathbf{N} \_\mathbf{R} * *$ & P_R $\mathbf{R}^{* *}$ & K_R** \\
\hline & \multicolumn{3}{|c|}{------------.\% } & \multicolumn{6}{|c|}{-------------------------mg plant ${ }^{-1}$} \\
\hline \multirow[t]{3}{*}{ CT } & & & & 8.50 & 0.36 & 14.06 & 2.43 & 0.18 & 2.13 \\
\hline & - & - & - & $\mathrm{AB}$ & B & A & A & A & A \\
\hline & & & & (4.21) & $(0.18)$ & (7.55) & $(0.75)$ & $(0.14)$ & (1.23) \\
\hline \multirow[t]{3}{*}{ DH } & 10.63 & 21.32 & 10.13 & 7.11 & 0.35 & 14.35 & 2.95 & 0.30 & 2.37 \\
\hline & A & A & A & $\mathrm{AB}$ & B & A & A & A & A \\
\hline & (70.85) & (54.97) & (56.71) & (1.39) & $(0.11)$ & (3.39) & (0.99) & $(0.24)$ & (1.25) \\
\hline \multirow[t]{3}{*}{ GM } & 13.18 & 20.52 & 12.04 & 6.29 & 0.28 & 13.44 & 2.62 & 0.36 & 2.29 \\
\hline & A & A & A & B & B & A & A & A & A \\
\hline & (74.55) & $(53.41)$ & (57.24) & (2.52) & $(0.16)$ & $(8.52)$ & $(0.60)$ & $(0.17)$ & (1.04) \\
\hline \multirow[t]{3}{*}{$\mathrm{RC}$} & 6.67 & 59.46 & 19.53 & 5.44 & 0.41 & 12.43 & 3.54 & 0.34 & 3.47 \\
\hline & A & A & A & B & $\mathrm{AB}$ & A & A & A & A \\
\hline & (100.11) & (93.88) & (89.69) & (1.95) & $(0.33)$ & (5.83) & (1.60) & $(0.22)$ & (1.59) \\
\hline \multirow[t]{3}{*}{ MT } & 54.20 & 35.91 & 44.19 & 12.25 & 0.64 & 19.09 & 3.55 & 0.25 & 2.72 \\
\hline & A & A & A & A & A & A & A & A & A \\
\hline & (119.25) & (58.35) & $(90.20)$ & (4.62) & (0.39) & (9.29) & $(0.97)$ & $(0.14)$ & (1.19) \\
\hline
\end{tabular}

${ }^{*}$ Values obtained from the average of 32 replicates/treatment. ${ }^{*}$ Values obtained from the average of 10 replicates/treatment. Values followed by different letters in the column indicate a significant difference between treatments, by the parametric LSD test or non-parametric Kruskal-

FLORESTA, Curitiba, PR, v. 50, n. 4, p. 1731 - 1740, out/dez 2020.

Silva, A. C. R. et.al.

ISSN eletrônico 1982-4688 
Wallis test ( $<$ 0.05). CT: control / absence of inoculation of seedlings with spores of arbuscular mycorrhizal fungi (AMF); DH: inoculation with Dentiscutata heterogama spores; GM: inoculation with Gigaspora margarita spores; RC: inoculation with Rhizophagus clarus spores; MT: inoculation with a mixture of spores of the three species of AMF.

There were no significant differences between treatments regarding their effect on RICD $(\mathrm{p}=0.263029)$, RIB_S ( $p=0.148950), R I B \_R(p=0.076266)$, RIB_T $(p=0.249664), K \_S(p=0.295860), N \_R(p=0.057804), P \_R$ $(p=0.225379), K \_R(p=0.151498), A B E \_P(p=0.537040)$, ABE_K $(p=0.296559), N U E \_N(p=0.270089)$ and NUE_K $(\mathrm{p}=0.324535)$.

Tabela 6. Valores médios de eficiência de absorção de nitrogênio, fósforo e potássio (ABE_N, ABE_P e ABE_K, respectivamente), e de eficiência de utilização de nitrogênio, fósforo e potássio (NUE_N, NUE_P e NUE_K, respectivamente), de mudas de Colubrina glandulosa em diferentes tratamentos de inoculação com fungos micorrízicos arbusculares (Trat) aos 140 dias após o transplantio das sementes pré-germinadas, em condições de casa de vegetação.

Table 6. Mean values of absorption efficiency of nitrogen, phosphorus, and potassium (ABE_N, ABE_P, and ABE_K, respectively), and utilization efficiency of nitrogen, phosphorus, and potassium (NUE_N, NUE_P, and NUE_K, respectively) of Colubrina glandulosa seedlings at 140 days after transplanting of pre-germinated seeds, in different treatments of arbuscular mycorrhizal fungi inoculation (Treat) under greenhouse conditions.

\begin{tabular}{|c|c|c|c|c|c|c|}
\hline \multirow[t]{2}{*}{ Treat } & ABE_N* & ABE_P* & ABE_K* & NUE_N* & NUE_P* & NUE_K* \\
\hline & \multicolumn{3}{|c|}{ 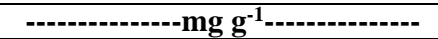 } & \multicolumn{3}{|c|}{ 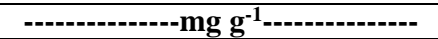 } \\
\hline \multirow[t]{3}{*}{ CT } & 12.67 & 0.64 & 18.80 & 1.17 & 23.78 & 0.87 \\
\hline & A & A & A & A & $\mathrm{AB}$ & A \\
\hline & (4.44) & $(0.25)$ & $(7.83)$ & $(0.53)$ & (12.28) & $(0.46)$ \\
\hline \multirow[t]{3}{*}{ DH } & 9.50 & 0.57 & 15.49 & 1.12 & 18.58 & 0.68 \\
\hline & $\mathrm{AB}$ & A & A & A & $\mathrm{AB}$ & A \\
\hline & $(2.51)$ & $(0.12)$ & $(3.96)$ & $(0.28)$ & $(6.25)$ & $(0.16)$ \\
\hline \multirow[t]{3}{*}{ GM } & 8.72 & 0.63 & 15.03 & 1.20 & 16.61 & 0.82 \\
\hline & $\mathrm{AB}$ & A & A & A & B & A \\
\hline & $(2.36)$ & $(0.22)$ & (6.69) & $(0.53)$ & $(6.15)$ & $(0.66)$ \\
\hline \multirow[t]{3}{*}{$\mathrm{RC}$} & 7.01 & 0.55 & 13.36 & 1.18 & 16.15 & 0.80 \\
\hline & B & A & A & A & B & A \\
\hline & $(0.86)$ & $(0.19)$ & $(5.32)$ & $(0.33)$ & $(6.62)$ & $(0.69)$ \\
\hline \multirow[t]{3}{*}{ MT } & 12.93 & 0.72 & 17.68 & 1.52 & 28.44 & 1.18 \\
\hline & A & A & A & A & A & A \\
\hline & $(3.44)$ & $(0.33)$ & (5.93) & $(0.45)$ & (7.65) & (0.58) \\
\hline
\end{tabular}

*Values obtained from the average of 32 replicates/treatment. Values followed by different letters in the column indicate a si gnificant difference between treatments, by the parametric LSD test or non-parametric Kruskal-Wallis test ( $<<0.05)$. CT: control / absence of inoculation of seedlings with spores of arbuscular mycorrhizal fungi (AMF); DH: inoculation with Dentiscutata heterogama spores; GM: inoculation with Gigaspora margarita spores; RC: inoculation with Rhizophagus clarus spores; MT: inoculation with a mixture of spores of the three species of AMF.

Principal component analysis, which was produced considering a total of 20 variables, showed that the MT treatment correlated with higher values of 10 variables (Figure 1a). On the other hand, the RC treatment was correlated only with the variables RDM and K_R, while the CT, DH and GM treatments did not correlate with any of the variables analyzed. 


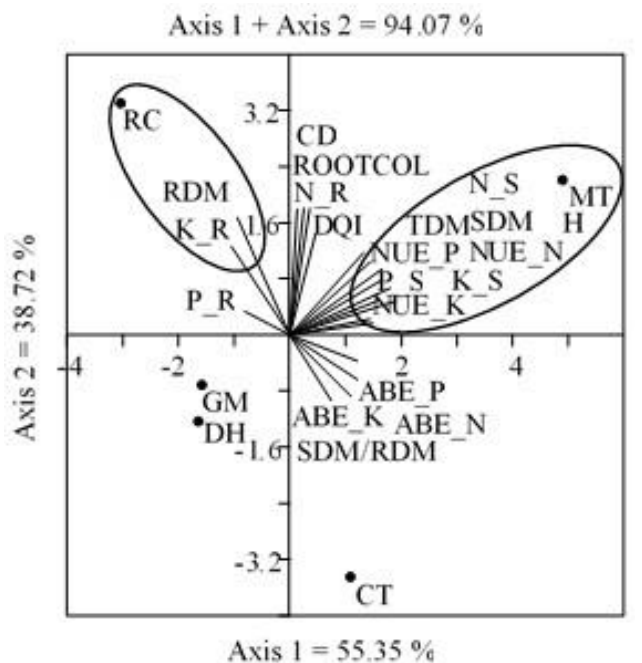

(a)

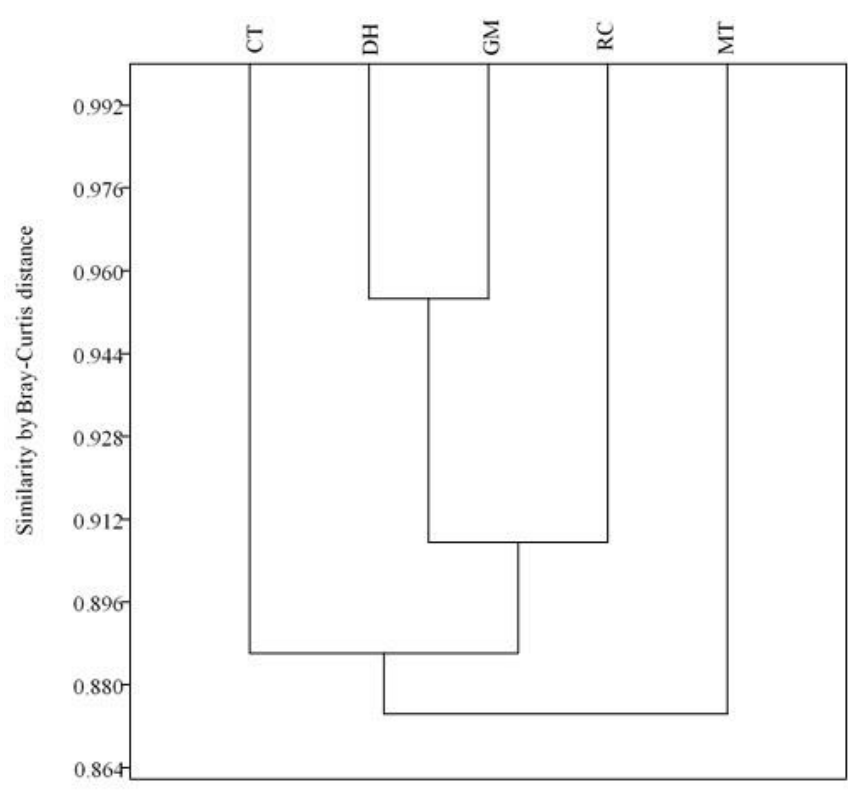

(b)

Figura 1. Análise dos componentes principais (a) e dendrograma de similaridade (b) do efeito dos tratamentos CT (controle / ausência de inoculação com fungos micorrízicos arbusculares), DH (inoculação com Dentiscutata heterogama), GM (inoculação com Gigaspora margarita), RC (inoculação com Rhizophagus clarus), MT (inoculação com a mistura de fungos micorrízicos arbusculares), para mudas de Colubrina glandulosa aos 140 dias após o transplantio das sementes pré-germinadas, em condições de casa de vegetação.

Figure 1. Principal components analysis (a) and dendrogram of similarity (b) for the effect of the treatments CT (control / absence of inoculation with arbuscular mycorrhizal fungi), DH (inoculation with Dentiscutata heterogama), GM (inoculation with Gigaspora margarita), RC (inoculation with Rhizophagus clarus), MT (inoculation with the mixture of the three arbuscular mycorrhizal fungi species), for Colubrina glandulosa seedlings at 140 days after transplanting of pre-germinated seeds.

Figure 1a indicated the individualization of the treatments among themselves, through the relationship between the principal components 1 and 2 (axes 1 and 2, respectively). The treatments CT and MT were grouped in the right part of axis 1 (positive values), while the treatments DH, GM and RC were grouped in the left part of this axis (negative values). Axis 1 was responsible for explaining $55.35 \%$ of the data variability found.

On the other hand, axis 2 individualized the treatments CT and MT, since the former was located in the lower part (negative values), while the latter was located in the upper part (positive values) of this axis (Figure 1a). In addition, the DH, GM and RC grouping was also individualized by axis 2, because the first two treatments (DH and GM) remained in the lower part (negative values) of this axis, while the RC treatment was isolated in the upper part (positive values) of axis 2 . Axis 2 explained $38.72 \%$ of data variability, and the set of axes 1 and 2 explained $94.07 \%$ of the variance of the observed data.

The hierarchical cluster dendrogram pointed to the formation of two large groups: one group was formed by the MT treatment alone, while the other was formed by CT, DH, GM and RC (Figure 1b). This second group, in turn, was subdivided into two subgroups: one that was represented alone by CT, and the other by the treatments DH, GM and RC. Therefore, this multivariate analysis demonstrated that there was a greater similarity between the treatments $\mathrm{DH}$, GM and RC with regard to their effects on the growth and nutritional status of the seedlings, while the effects caused on the seedlings by the treatments CT and MT differed from each other, and in the comparison with the other treatments.

\section{DISCUSSION}

The absence of root colonization in non-inoculated seedlings showed that the control was effective. Root colonization rates of Colubrina glandulosa seedlings were considered low $(\leq 20 \%)$, regardless of the mycorrhizal inoculum employed (single species of AMF or the mixture of the three species). This result was due to the high total phosphorus content in the biosolid (ABREU et al., 2019), which probably promoted high availability of this nutrient for the seedlings. In general, under conditions of greater availability of phosphorus in the soil solution, the plant does not stimulate the formation of symbiosis with AMF (CAMARA et al., 2017), whose maintenance would constitute an energy burden without due benefit for it (SOUZA et al., 2009). Therefore, under these conditions, there are low rates of root colonization by AMF (SMITH et al., 2010). (56 \%) (OLIVEIRA JÚNIOR et al., 2017). For Apuleia leiocarpa (Vogel) J. F. Macbr (garapa), the rate of mycorrhizal colonization in the root system of seedlings produced in substrate with addition of the highest doses of phosphorus $\left(650 \mathrm{mg} \mathrm{kg}^{-1}\right)$ was on the order of $8 \%$, whereas with the addition of the

FLORESTA, Curitiba, PR, v. 50, n. 4, p. 1731 - 1740, out/dez 2020.

Silva, A. C. R. et.al.

ISSN eletrônico 1982-4688 
lowest dose of this nutrient in the substrate $\left(24 \mathrm{mg} \mathrm{kg}^{-1}\right)$, the rate of mycorrhizal colonization of the root system of seedlings was seven times higher (56\%) (OLIVEIRA JÚNIOR et al., 2017).

However, the lower rate of root colonization does not necessarily imply absence of nutritional gains and growth for seedlings (LIMA et al., 2015). The mycorrhizal colonization rate of Colubrina glandulosa was significantly lower $(18 \%)$ in the treatment $\mathrm{T} 8(60 \%$ soil from A horizon $+20 \%$ bovine manure $+10 \%$ sand $+10 \%$ vermiculite $)$, compared to the colonization rate $(39 \%)$ in T4 $(60 \%$ soil from A horizon $+20 \%$ bovine manure $+20 \%$ sand) (CAMARA et al., 2017). On the other hand, the former treatment (T8) promoted the production of seedlings with higher quality (SDM: $1.44 \mathrm{~g}$; RDM: $1.21 \mathrm{~g}$; DQI: 0.53), compared to those produced on the T4 substrate (SDM: $0.90 \mathrm{~g}$; RDM: $0.35 \mathrm{~g}$; DQI: 0.21 ), according to the authors mentioned above.

The hypothesis that there is a difference in the response of Colubrina glandulosa according to the inoculum of AMF was corroborated, since inoculation with the mixture of three different species of AMF (Rhizophagus clarus, Gigaspora margarita and Dentiscutata heterogama) promoted increments of growth and nutritional status in the seedlings, compared to single inoculation of each AMF species and also to the control (absence of inoculation). This pattern indicated the existence of synergism and complementation between different strategies of soil exploration and root colonization of each AMF species, in comparison to a single AMF species, for seedlings of the same species of host plant (MARTIN et al., 2012). Such strategies, therefore, vary according to the species of AMF and, in the case of mixed inoculum, may lead to greater benefits for the seedlings, compared to seedlings inoculated with only one species of these fungi (OLIVEIRA JÚNIOR et al., 2017).

According to the above, the mycorrhizal benefit may vary even in the comparison between inocula from different AMF mixtures for the same plant species, as verified in previous studies conducted in greenhouse. Inoculation with the mixture of Glomus etunicatum and Gigaspora margarita spores generated increments of height, leaf area, shoot dry mass and root dry mass of Anadenanthera macrocarpa (Benth) Brenan (angico) seedlings, compared to the mixture of Glomus etunicatum and Paraglomus brasilianum (Spain and J. Miranda) J. B. Morton and D. Redecker, at 150 days after germination of the seeds of this forest species (SUGAI et al., 2011). Toona ciliata seedlings inoculated with the mixture of Glomus clarum and Glomus etunicatum showed significant increments in stem diameter and shoot dry mass, when compared to the mixture of Glomus clarum and Gigaspora margarita at140 days after seed germination (LIMA et al., 2015).

However, mixed inocula do not always promote increments in growth and nutritional conditions of seedlings of forest species, compared to inoculation with a single species of AMF. Aspidosperma polyneuron Müll. Arg. seedlings with 120 days showed better growth (height, shoot dry mass and root dry mass) and nutrient accumulation (phosphorus, potassium, calcium, magnesium, boron, copper and zinc) due to single inoculation with Gigaspora margarita, in comparison to the inoculum obtained by mixing spores of this AMF species and Glomus clarum (currently classified as Rhizophagus clarus), Acaulospora scrobiculata Trappe and Scutellospora heterogama (Nicol and Gerd) Walker and Sanders (MACHINESKI et al., 2009). The differences in the effect of inoculation of seedlings with AMF, either for mixed inocula or only one species of AMF, are due to the fact that the interaction between these microorganisms and the plant host is a biological and evolutionary process (LAGUNAS et al., 2015).

Therefore, the benefit generated by mycorrhiza depends on the conjunction of three factors: (1) edaphic conditions, such as the availability of phosphorus for plants in the soil, which was previously discussed, (2) the AMF involved (ROCHA et al., 2006) and (3) the plant species considered (SCABORA et al., 2010). This picture demonstrates the importance of conducting experiments to investigate the effect of inocula containing spores of only one species and of various mixtures with different species of AMF, for the same plant species, and in substrates containing different conditions of nutrient availability (phosphorus), so that the most appropriate treatment for obtaining seedlings of forest species with higher quality focused on the recovery of degraded areas can be recommended.

\section{CONCLUSIONS}

- Inoculation with the mixture of spores of different species of arbuscular mycorrhizal fungi promoted the production of Colubrina glandulosa seedlings with higher quality, compared with the single inoculation with Rhizophagus clarus, Gigaspora margarita and Dentiscutata heterogama and the control in the biosolid-based substrate tested (80\% sewage sludge from sewage treatment plant and $20 \%$ vermiculite).

\section{REFERENCES}

ABREU, A. H. M.; ALONSO, J. M.; MELO, L. A.; LELES, P. S. S.; SANTOS, G. R. Caracterização de biossólido e potencial de uso na produção de mudas de Schinus terebinthifolia Raddi. Engenharia Sanitária e Ambiental, Rio de Janeiro, v. 24, n. 3, p. 591 - 599, 2019.

BRANCALION, P. H. S.; MONDO, V. H. V.; COELHO, A. D. L. Escarificação química para a superação da dormência de sementes de saguaraji-vermelho (Colubrina glandulosa Perk. - Rhamnaceae). Revista Árvore, Viçosa, v. 35, n. 1, p. 119 - 124, 2011.

CAMARA, R.; FONSECA JÚNIOR, A. M.; SOUSA, A. C. O.; PEREIRA, M. G.; OLIVEIRA JÚNIOR, J. Q. Influência do substrato e inoculação micorrízica na produção de mudas de Colubrina glandulosa Perkins. Floresta, Curitiba, v. 47, n. 4, p. 449 - 458, 2017.

FLORESTA, Curitiba, PR, v. 50, n. 4, p. 1731 - 1740, out/dez 2020.

Silva, A. C. R. et.al.

ISSN eletrônico 1982-4688

DOI: $10.5380 /$ rf.v50 i4. 60840 
CARMO, E. R.; SILVA, C. F.; FREITAS, M. S. M.; LIMA, K. B.; MARTINS, M. A. Production of australian cedar seedlings inoculated with arbuscular mycorrhizal fungi in different types of containers. Revista Árvore, Viçosa, v. 40, n. 2, p. 269 - 278, 2016.

FOLLI-PEREIRA, M. S.; MEIRA-HADDAD, L. S.; BAZZOLLI, D. M. S.; KASUYA, M. C. M. Micorriza arbuscular e a tolerância das plantas ao estresse, Revista Brasileira de Ciência do Solo, Viçosa, v. 36, n. 6, p. 1663 - $1679,2012$. GAMA, M. M. B.; ROCHA, R.B.; SALMAN, A. K. D.; MENDES, A. M.; FIGUEIRÓ, M. R. Reforestation feasibility in area formerly used for cattle raising in the state of Rondônia, northwest Brazilian Amazon. Revista Árvore, Viçosa, v. 37, n. 6, p. 1001 - 1010, 2013.

GOMES, D. R.; CALDEIRA, M. V. W.; DELARMELINA, W. M.; GONÇALVES, E. O.; TRAZZI, P. A. Lodo de esgoto como substrato para a produção de mudas de Tectona grandis L. Cerne, Lavras, v. 19, n. 1, p. 123 - 131, 2013. GRACE, C.; STRIBLEY, D. P. A safer procedure for routine staining of vesicular-arbuscular mycorrhizal fungi. Mycological Research, Cambridge, v. 95, n. 10, p. 1160 - 1162, 1991.

KOSKE, R. E.; GEMMA, J. N. A modified procedure for staining roots to detect VA mycorrhizas. Mycological Research, Cambridge, v. 92, n. 4, p. 486 - 488, 1989.

LAGUNAS, B.; SCHÄFER, P.; GIFFORD, M. L. Housing helpful invaders: the evolutionary and molecular architecture underlying plant root-mutualist microbe interactions. Journal of Experimental Botany, Oxford, v. 66, n. 8, p. 2177 2186, 2015.

LIMA, K. B.; RITER NETTO, A. F.; MARTINS, M. A.; FREITAS, M. S. M. Crescimento, acúmulo de nutrientes e fenóis totais de mudas de cedro-australiano (Toona ciliata) inoculadas com fungos micorrízicos. Ciência Florestal, Santa Maria, v. 25, n. 4, p. 853 - 862, 2015.

MACHINESKI, O.; BALOTA, E. L.; COLOZZI FILHO, A.; ANDRADE, D. S.; SOUZA, J. R. P. Crescimento de mudas de peroba rosa em resposta à inoculação com fungos micorrízicos arbusculares Ciência Rural, Santa Maria, v. 39, n. 2, p. 567 - 570, 2009.

MARTIN, S. L.; MOONEY, S. J.; DICKINSON, M. J.; WEST, H. M. The effects of simultaneous root colonisation by three Glomus species on soil pore characteristics. Soil Biology and Biochemistry, Oxford, v. 49, p. 167 - 173, 2012.

OLIVEIRA JÚNIOR, J. Q.; JESUS, E. C.; PEREIRA, M. G.; CAMARA, R.; FONSECA JÚNIOR, A. M.; SOUSA, A. C. O. Dependency and response of Apuleia leiocarpa to inoculation with different species of arbuscular mycorrhizal fungi. Revista Brasileira de Ciência do Solo, Viçosa, v. 41, e0160174, 2017.

ROCHA, F. S.; SAGGIN JÚNIOR, O. J.; SILVA, E. M. R.; LIMA, W. L. Dependência e resposta de mudas de cedro a fungos micorrízicos arbusculares. Pesquisa Agropecuária Brasileira, Brasília, v. 41, n. 1, p. 77 - 84, 2006.

RODRIGUES, R. R.; TORRES, R. B.; MATTHES, L. A. F.; PENHA, A. S. Tree species sprouting from root buds in a Semideciduous Forest affected by fires. Brazilian Archives of Biology and Technology, Curitiba, v. 47, n. 1, p. 127 $133,2004$.

SCABORA, M. H.; MALTONI, K. L.; CASSIOLATO, A. M. R. Crescimento, fosfatase ácida e micorrização de espécies arbóreas, em solo de Cerrado degradado. Bragantia, Campinas, v. 69, n. 2, p. 445 - 451, 2010.

SIDDIQI, M. Y.; GLASS, A. D. M. Utilization index: a modified approach to the estimation and comparison of nutrient utilization efficiency in plants. Journal of Plant Nutrition, Oxford, v. 4, p. 289 - 302, 1981.

SILVA, K. A.; MARTINS, S. V.; MIRADA NETO, A.; CAMPOS, W. H. Semeadura direta com transposição de serapilheira como metodologia de restauração ecológica. Revista Árvore, Viçosa, v. 39, n. 5, p. 811 - 820, 2015.

SMITH, S. E.; FACELLI, E.; POPE, S.; SMITH, F. A. Plant performance in stressful environments: interpreting new and established knowledge of the roles of arbuscular mycorrhizas. Plant and Soil, Dordrecht, v. 326, n. 1, p. 3 - 20 , 2010.

SOUZA, R. C.; PEREIRA, M. G.; GIÁCOMO, R. G.; SILVA, E. M. R.; MENEZES, L. F. T. Produção de mudas micorrizadas de Schinus terebinthifolius Raddi. em diferentes substratos. Floresta, Curitiba, v. 39, n. 1, p. 197 - 206 , 2009.

SUGAI, M. A. A.; COLLIER, L. S.; SAGGIN-JÚNIOR, O. J. Inoculação micorrízica no crescimento de mudas de angico em solo de cerrado. Bragantia, Campinas, v. 70, n. 2, p. 416 - 423, 2011.

SWIADER, J. M.; CHYAN, Y.; FREIJI, F. G. Genotypic differences in nitrate uptake and utilization efficiency in pumpkin hybrids. Journal of Plant Nutrition, London, v. 17, n. 10, p. 1687 - 1699, 1994.

TEDESCO, M. J.; GIANELLO, C.; BISSANI, C. A.; BOHNEN, H.; VOLKWEISS, S. J. Análise de solo, plantas e outros materiais. Porto Alegre: Universidade Federal do Rio Grande do Sul, 2 ed. 1995, 147 p. (Boletim técnico, 5).

TRIGUEIRO, R. M.; GUERRINI, I. A. Utilização de lodo de esgoto na produção de mudas de aroeira-pimenteira. Revista Árvore, Viçosa, v. 38, n. 4, p. 657 - 665, 2014.

FLORESTA, Curitiba, PR, v. 50, n. 4, p. 1731 - 1740, out/dez 2020.

Silva, A. C. R. et.al.

ISSN eletrônico 1982-4688 